\title{
APLIKASI ANALYTICAL HIERARCHY PROCESS (AHP) DALAM MEMILIH PEMASOK PADA KSU POM HUMBANG COOPERATIVE
}

\author{
Josua Boyke William Jawak ${ }^{1)}$, Christoper Janwar Saputra Sinaga ${ }^{2)}$ \\ ${ }^{123}$ Fakultas Teknologi Industri, Institut Teknologi Del \\ email: josuaboyke@gmail.com, christoper.sinaga88@gmail.com
}

\begin{abstract}
Abstrak: KSU POM Humbang Cooperative merupakan produsen kopi dengan merk Sumatera Lintong Coffee. Kopi diproduksi menjadi 3 varian produk yaitu Sumatera Lintong Coffee Grade 1, Sumatera Lintong Coffee Grade 2 dan Sumatera Lintong Luwak Coffee, dimana Sumatera Lintong Grade 1 dan Sumatera Lintong Luwak Coffee adalah varian yang lebih bernilai dan lebih diminati. Namun karena ketidaksesuaian antara spesifikasi pasokan kopi dengan yang ditetapkan, produk Sumatera Lintong Coffee Grade 2 menjadi terlau banyak diproduksi. Penelitian ini bertujuan untuk mengidentifikasi kriteria dan sub kriteria pemilihan yang paling penting dalam menentukan pemasok biji kopi yang paling potensial. Metode yang diterapkan dalam penelitian ini adalah Analytical Hierarchy Process (AHP), sedangkan untuk mengidentifikasi kriteria dan sub kriteria dilakukan wawancara dan diskusi dengan pihak koperasi. Berdasarkan analisis, didapatkan kriteria yang paling penting dari pemilihan pemasok gabah kopi adalah kualitas dengan bobot 0,6223, sub kriteria yang paling penting adalah kesesuaian gabah dengan spesifikasi dengan bobot 0,5030 dan pemasok gabah kopi yang paling potensial adalah Gani Silaban dengan bobot 0,2194. Kriteria yang paling penting dari pemilihan pemasok greenbean kopi adalah kualitas dengan bobot 0,54 , sub kriteria yang paling penting adalah kesesuaian greenbean dengan spesifikasi dengan bobot 0,4381 dan pemasok greenbean kopi yang paling potensial adalah Toke MS.
\end{abstract}

Kata kunci: Pemilihan Pemasok, Analytical Hierarchy Process, Supplier, Kriteria, Sub Kriteria

Abstract: KSU POM Humbang Cooperative is a coffee producer with Sumatera Lintong Coffee brand. Coffee is produced into 3 product variants, there are Sumatera Lintong Coffee Grade 1, Sumatera Lintong Coffee Grade 2, and Sumatera Lintong Luwak Coffee, where Sumatera Lintong Coffee Grade 1 and Sumatera Lintong Luwak Coffee are more valuable and more desirable types. However, due to a mismatch between the coffee supply specifications and those specified, the Sumatera Lintong Coffee Grade 2 product becomes too much produced. This study aims to identify the criteria and sub criteria that are most important in supplier selection to determining the most potential coffee bean suppliers. The method applied in this study is the Analytical Hierarchy Process (AHP) to determine the importance weight of each criteria, sub-criteria and supplier. Interviews and discussions were conducted to identify criteria and sub-criteria. Based on the analysis, the most important criteria obtained from the selection of coffee grain suppliers is quality with a weight of 0.6223 , the most important sub criteria are grain suitability with specifications with a weight of 0.5030 and the most potential supplier of coffee grain is Gani Silaban with a weight of 0.2194. The most important criterion of selecting greenbean coffee suppliers is quality with a weight of 0.54 , the most important sub-criteria is the suitability of the greenbean with specifications with a weight of 0.4381 and the most potential greenbean coffee supplier is Toke MS.

Keywords: Supplier Selection, Analytical Hierarchy Process, Supplier, Criteria, Sub Criteria

\section{PENDAHULUAN}

Industri kopi merupakan kegiatan ekonomi yang mengolah buah kopi (coffee cherry) menjadi bubuk kopi yang siap untuk di konsumsi. Proses pengolahan kopi dimulai dari panen buah kopi yang kemudian biji dan kulit buah dipisahkan. Biji kopi kemudian akan melalui proses 
pengeringan, pengupasan, sangrai dan grinder. Hasil akhir dari proses ini yaitu bubuk kopi yang siap untuk dikonsumsi. Baik atau tidaknya setiap proses pengolahan yang dilakukan berpengaruh terhadap rasa ataupun aroma dari kopi saat dikonsumsi. Perbedaan kualitas biji kopi yang diolah juga akan menghasilkan perbedaan terhadap rasa ataupun aroma kopi. Perbedaan kualitas kopi ini menyebabkan adanya selisih harga saat akan dipasarkan ke masyarakat.

KSU POM Humbang Cooperative merupakan UKM yang berdiri dalam bentuk koperasi dan bergerak dalam industri kopi. UKM ini berlokasi di Desa Nagasaribu II, Kecamatan Lintongnihuta, Kabupaten Humbang Hasundutan. Koperasi ini memproduksi kopi arabika yang terdiri dari 3 varian produk yaitu Sumatera Lintong Coffee Grade 1, Sumatera Lintong Coffee Grade 2 dan Sumatera Lintong Luwak Coffee. Produksi pada koperasi dilakukan mulai dari proses pengolahan biji kopi yang sudah berupa gabah kopi. Menurut (Towaha \& Rubiyo, 2016) gabah kopi merupakan biji kopi dengan kulit tanduk setelah perlakuan fermentasi probiotik. Seluruh varian produk diproduksi mulai dari tahap tersebut. Varian kopi luwak diolah dari biji kopi arabika yang berasal dari sisa kotoran luwak. Sedangkan varian kopi arabika grade 1 dan grade 2 merupakan kopi yang berasal dari biji kopi dengan kualitas yang berbeda. Perbedaan kualitas disebabkan adanya cacat dari biji kopi yang diolah, dimana, setiap adanya biji kopi yang cacat akan dipisahkan karena biji yang cacat merupakan biji yang tidak sesuai dengan spesifikasi yang sudah ditentukan. Spesifikasi dari biji kopi yang diolah oleh koperasi yaitu biji kopi yang tidak memiliki jenis cacat biji hitam, biji cokelat, biji pecah, biji muda, biji berlubang dan biji bertutul-tutul.

Cacat pada biji kopi bersumber dari pengolahan kopi baik pra maupun pasca panen. Biji kopi hitam dan cokelat merupakan biji yang berasal dari buah kopi yang terkena penyakit, biji berlubang merupakan biji yang berasal dari buah kopi yang terkena serangan serangga, dan biji kopi pecah umumnya karena buah kopi masih terlalu muda saat dipanen sehingga pada proses pengupasan kulit buah kopi menjadi pecah (Setyani, 2018).

Harga untuk setiap varian produk yang dijual oleh koperasi berbeda-beda, dimana untuk Sumatera Lintong Luwak Coffee seharga Rp. 100.000/100gr, Sumatera Lintong Coffee Grade 1 dijual seharga Rp. 40.000/250gr, dan Sumatera Lintong Coffee Grade 2 seharga Rp. 20.000/200gr. Harga kopi Sumatera Lintong Coffee untuk grade 2 lebih murah $60 \%$ dibandingkan dengan grade 1, tentunya hal ini dikarenakan kualitas yang berbeda dari biji yang diolah.

Dalam memproduksi varian Sumatera Lintong Coffee untuk grade 1 dan Grade 2, koperasi memiliki jumlah produksi yang tidak berbeda jauh, hal itu diperlihatkan dari data laporan produksi. Berikut ini adalah data laporan produksi dan penjualan Sumatera Lintong Coffee tahun 2018 mulai dari bulan OktoberDesember:

Tabel 1. Laporan Produksi dan Laporan Penjualan

\begin{tabular}{|l|r|r|}
\hline \multicolumn{3}{|c|}{ LAPORAN PRODUKSI } \\
\hline Bulan & Grade 1 (kg) & Grade 2 (kg) \\
\hline Oktober & 416,875 & 402,5 \\
\hline November & 445,625 & 425,5 \\
\hline Desember & 575 & 483 \\
\hline Total & 1437,5 & 1311 \\
\hline \multicolumn{3}{|c|}{ LAPORAN PENJUALAN } \\
\hline Bulan & Grade 1 (kg) & Grade 2 (kg) \\
\hline Oktober & Rp58.000.000 & Rp35.000.000 \\
\hline November & Rp62.000.000 & Rp37.000.000 \\
\hline Desember & Rp80.000.000 & Rp42.000.000 \\
\hline Total & Rp200.000.000 & Rp114.000.000 \\
\hline
\end{tabular}

Sumber: KSU POM Cooperative

Dari data tersebut terlihat bahwa produksi grade 2 cukup besar dengan jumlah yaitu $1311 \mathrm{~kg}$. Berdasarkan data tersebut juga dapat diketahui persentase jumlah produksi kopi grade 1 dan grade 2 yaitu $52 \%$ grade 1 dan $47 \%$ grade 2 . Perbedaan harga kopi antara grade 1 dan 
grade 2 membuat keuntungan yang seharusnya dapat lebih banyak menjadi lebih sedikit, hal ini juga diperlihatkan data penjualan kopi grade 2 sebesar Rp. 114.000.000 sangat jauh berbeda dengan penjualan grade 1 yaitu Rp. 200.000.000 padahal jumlah kopi yang dijual tidak berbeda jauh.

Proses produksi kopi pada koperasi ini dimulai dari pengolahan gabah kopi. Hal ini mengindikasikan bahwa biji kopi yang dipasok banyak yang tidak sesuai dengan spesifikasi yang sudah ditentukan. Kualitas dari pasokan dipengaruhi oleh kondisi, cara maupun alat yang digunakan mulai dari penanaman, pemupukan, pemanenan dan pengolahan sampai pengiriman kepada koperasi. Perbedaan pengetahuan dari setiap petani menyebabkan berbeda pula kualitas yang mereka pasok sehingga adanya ketidaksesuaian antara yang diminta dengan yang diterima oleh koperasi. Koperasi ini belum melakukan pemilihan pemasok sebelumnya sehingga semua pemasok yang ada diterima pasokannya tanpa dilakukan seleksi kesesuaian terhadap mereka. Koperasi juga belum menentukan tingkatan performa dari setiap pemasok secara terstruktur menyebabkan kesulitan dalam memilih pemasok yang harus diprioritaskan ataupun yang memerlukan perhatian khusus. Metode Analytical Hierarchy Proses (AHP) merupakan salah satu metode yang digunakan dalam mengambil keputusan dari sebuah masalah kompleks. Metode ini mengurutkan setiap alternatif -alternatif penyelesaian masalah berdasarkan penilaian pembuat keputusan dengan memperhatikan pentingnya suatu kriteria dan sejauh mana kriteria-kriteria tersebut dipenuhi oleh setiap alternatif.

Berdasarkan hal tersebut penulis mempertimbangkan pentingnya pemilihan pemasok untuk Sumatera Lintong Coffee. Aplikasi atau penerapan metode AHP dapat dilakukan dalam membuat keputusan untuk memilih pemasok biji kopi yang paling sesuai dengan kebutuhan dari KSU POM Humbang Cooperative. Luaran dari penelitian ini dapat dimanfaatkan KSU POM Cooperative dalam memilih pemasok yang akan memasok biji kopi sesuai kriteria yang telah ditentukan agar produksi Sumatera Lintong Kopi Grade 1 meningkat dengan persentase dari produksi total di atas dari 52 persen. Melihat pemasok yang lebih banyak adalah petani yang merupakan anggota koperasi maka penelitian ini juga dapat dimanfaatkan oleh KSU POM Humbang Cooperative dalam menentukan petani yang membutuhkan perhatian khusus untuk meningkatkan pasokan mereka, baik dari kualitas pasokan maupun kriteria-kriteria lain yang sesuai dengan kebutuhan koperasi.

\section{METODE PENELITIAN}

Pada penelitian ini metodologi dimulai dari studi pendahuluan, studi literatur, pengumpulan data, pengolahan data dan analisis data.

1. Studi Pendahuluan

Penulis mempelajari proses produksi dan penentuan kualitas kopi di KSU POM Cooperative.

2. Studi Literatur

Mempelajari teori serta konsep yang sesuai terhadap penelitian.

3. Pengumpulan Data

Pengumpulan berkaitan dengan persyaratan menjadi pemasok, alasan penerimaan dan penolakan pemasok serta data penilaian setiap kriteria. Metode yang digunakan dalam pengumpulan data adalah wawancara, observasi dan kuesioner.

4. Pengolahan Data

Pengolahan dilakukan berdasarkan data yang sudah dikumpulkan yang terlebih dahulu dibuat dalam sebuah struktur hierarki kemudian dilakukan penghitungan bobot untuk masing-masing kriteria, sub kriteria dan pemasok menggunakan metode Analytical Hierarchy Process (AHP). Pengolahan data AHP berupa pengolahan data horizontal dan vertikal.

5. Analisis Data 
Data yang sudah diolah kemudian dianalisis untuk ditentukan kriteria, performa dan urutan pemasok.

Langkah dalam menggunakan metode AHP dalam menyelesaikan masalah adalah:

1. Mendefenisikan persoalan dan membuat dalam struktur hierarki.

2. Menyusun matriks perbandingan berpasangan.

3. Mendapatlan semua pertimbangan yang diperlukan untuk mengembangkan perangkat matriks di langkah 3.

4. Memasukkan nilai-nilai kebalikannya beserta bilangan 1 sampai 9 sepanjang diagonal utama.

5. Melaksanakan langkah 3, 4, dan 5 untuk semua tingkat dan gugusan dalam hierarki tersebut.

6. Menggunakan komposisi secara hierarki untuk membobotkan vektor prioritas. Vektor prioritas dapat dihitung dengan rumus:

$\mathrm{VP}($ Vektor Prioritas $)=\frac{V E}{\sum_{i=1}^{n} V E}$

Dimana:

VE (Vektor Eigen) $=\sqrt[n]{\sum_{j=1}^{n} a_{i j}}$

Dengan $a_{i j}=$ elemen baris ke-i dan kolom ke-j $\mathrm{n}=$ jumlah elemen

7. Mengevaluasi inkonsistensi, rasio konsistensi (CR) hierarki harus 10\% atau kurang. Rumus untuk perhitungan uji konsistensi adalah sebagai berikut:

- $\mathrm{CR}=\frac{C I}{R I}$

Dengan:

- $\mathrm{CI}=\frac{\lambda m a k s-n}{n-1}$

$\mathrm{CI}=$ Indeks Konsistensi

$\lambda$ maks $=$ eigen value maksimum

$\mathrm{n} \quad=$ jumlah elemen

Dimana:

$\lambda$ maks $\quad=\frac{\sum V B}{n}$

$\mathrm{VB}$ (Nilai Eigen) $=\frac{V A}{V P}$

$\mathrm{VA}($ Vektor Antara $)=a_{i j} \mathrm{VP}$
Berikut ini tabel random index (RI):

Tabel 2. Nilai Random Index

\begin{tabular}{|c|c|}
\hline $\begin{array}{c}\mathbf{n} \\
\text { (jumlah faktor) }\end{array}$ & RI \\
\hline 2 & 0 \\
\hline 3 & 0,58 \\
\hline 4 & 0,9 \\
\hline 5 & 1,12 \\
\hline 6 & 1,24 \\
\hline 7 & 1,32 \\
\hline 8 & 1,41 \\
\hline 9 & 1,45 \\
\hline 10 & 1,51 \\
\hline
\end{tabular}

Sumber: (Firdaus \& M.A, 2008)

\section{HASIL DAN PEMBAHASAN}

\section{A. Hierarki Pemilihan Pemasok}

1. Pemilihan Pemasok Gabah Kopi

Berikut ini adalah hierarki pemilihan pemasok gabah kopi:

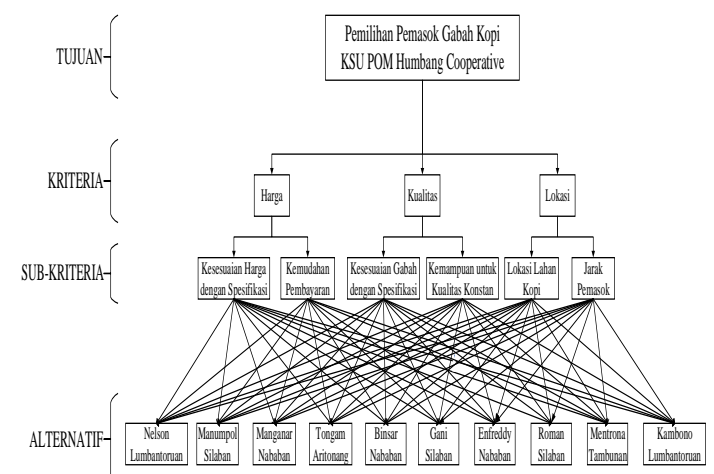

Gambar 1. Hierarki Pemilihan Pemasok Gabah Kopi

2. Pemilihan Pemaosk Greenbean Kopi Berikut ini adalah hierarki pemilihan pemasok untuk greenbean kopi:

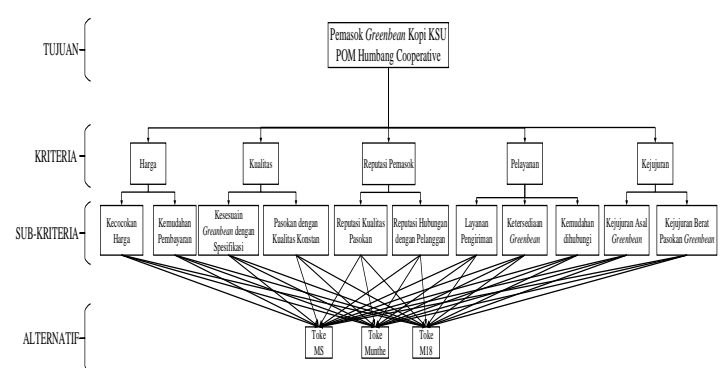

Gambar 2. Hierarki Pemilihan Pemasok Greenbean Kopi

\section{B. Pengolahan Data Pemilihan Pemasok Gabah Kopi}

1. Pengolahan Data Secara Horizontal Hasil pengolahan data horizontal pada pemasok gabah kopi terdiri dari 
pengolahan pada elemen kriteria, sub kriteria dan alternatif. Berikut ini hasil pengolahan data secara horizontal untuk elemen kriteria:

Tabel 3. Hasil Pengolahan Data Horizontal Elemen Kriteria Gabah Kopi

\begin{tabular}{|l|c|c|}
\hline \multicolumn{1}{|c|}{ Kriteria } & Bobot & \multicolumn{1}{c|}{ CR } \\
\hline Harga & 0,1569 & \multirow{2}{*}{0,0044} \\
\cline { 1 - 2 } Kualitas & 0,6223 & \multirow{2}{*}{0,2208} \\
\hline Lokasi & 0,2 \\
\hline
\end{tabular}

Berikut ini hasil pengolahan data secara horizontal untuk elemen sub kriteria:

Tabel 4. Hasil Pengolahan Data Horizontal Elemen Sub Kriteria Gabah Kopi

\begin{tabular}{|c|c|c|c|c|}
\hline Sub Kriteria & Harga & Kualitas & Lokasi & $\mathrm{CI}$ \\
\hline $\begin{array}{l}\text { Kesesuaian } \\
\text { Harga dengan } \\
\text { Spesifikasi (A1) }\end{array}$ & 0,6940 & & & 0 \\
\hline $\begin{array}{l}\text { Kemudahan } \\
\text { Pembayaran } \\
\text { (A2) }\end{array}$ & 0,3060 & & & \\
\hline $\begin{array}{l}\text { Kesesuaian } \\
\text { Gabah dengan } \\
\text { Spesifikasi (A3) }\end{array}$ & & 0,8083 & & 0 \\
\hline $\begin{array}{l}\text { Kemampuan } \\
\text { untuk Kualitas } \\
\text { Konstan (A4) }\end{array}$ & & 0,1917 & & \\
\hline $\begin{array}{l}\text { Lokasi Lahan } \\
\text { Kopi (A5) }\end{array}$ & & & 0,8333 & 0 \\
\hline $\begin{array}{l}\text { Jarak Pemasok } \\
\text { (A6) }\end{array}$ & & & 0,1667 & \\
\hline
\end{tabular}

Berikut ini hasil pengolahan data secara horizontal untuk elemen alternatif:

Tabel 5. Hasil Pengolahan Data Horizontal Elemen Alternatif Gabah Kopi

\begin{tabular}{|l|c|c|c|c|c|c|}
\hline Alternatif & $\mathrm{A} 1$ & $\mathrm{~A} 2$ & $\mathrm{~A} 3$ & $\mathrm{~A} 4$ & $\mathrm{~A} 5$ & $\mathrm{~A} 6$ \\
\hline & 0,09 & 0,06 & 0,05 & 0,09 & 0,11 & 0,12 \\
Nelson L. & 9 & 7 & 0 & 6 & 1 & 4 \\
\hline & 0,03 & 0,04 & 0,03 & 0,02 & 0,01 & 0,02 \\
Manumpol & 3 & 1 & 3 & 1 & 1 & 8 \\
\hline & 0,02 & 0,11 & 0,07 & 0,03 & 0,14 & 0,12 \\
Manganar & 1 & 2 & 1 & 4 & 3 & 4 \\
\hline & 0,15 & 0,11 & 0,15 & 0,15 & 0,05 & 0,07 \\
Tongam & 9 & 2 & 9 & 9 & 9 & 9 \\
\hline & 0,20 & 0,17 & 0,19 & 0,19 & 0,18 & 0,18 \\
Binsar N. & 1 & 5 & 7 & 6 & 2 & 2 \\
\hline \multirow{2}{*}{ Gani S. } & 0,23 & 0,17 & 0,23 & 0,23 & 0,18 & 0,18 \\
& 4 & 5 & 3 & 3 & 2 & 2 \\
\hline \multirow{2}{*}{ Enfreddy } & 0,01 & 0,02 & 0,01 & 0,05 & 0,02 & 0,04 \\
& 3 & 5 & 3 & 0 & 7 & 9 \\
\hline \multirow{2}{*}{ Roman S. } & 0,12 & 0,11 & 0,12 & 0,07 & 0,18 & 0,02 \\
& 2 & 2 & 6 & 1 & 2 & 8 \\
\hline \multirow{2}{*}{ Mentrona } & 0,04 & 0,11 & 0,02 & 0,01 & 0,04 & 0,12 \\
& 8 & 2 & 1 & 2 & 1 & 4 \\
\hline
\end{tabular}

\begin{tabular}{|l|c|c|c|c|c|c|}
\hline Alternatif & A1 & A2 & A3 & A4 & A5 & A6 \\
\hline \multirow{2}{*}{ Kambono } & 0,06 & 0,06 & 0,09 & 0,12 & 0,06 & 0,07 \\
& 7 & 8 & 6 & 5 & 0 & 9 \\
\hline \multirow{2}{*}{ CR } & 0,06 & 0,01 & 0,06 & 0,06 & 0,05 & 0,01 \\
& 7 & 0 & 3 & 3 & 0 & 3 \\
\hline
\end{tabular}

2. Pengolahan Data Secara Vertikal

Hasil pengolahan data vertikal pada pemasok gabah kopi terdiri dari pengolahan pada elemen kriteria, sub kriteria dan alternatif. Berikut ini hasil pengolahan data secara vertikal untuk elemen kriteria:

Tabel 6.Hasil Pengolahan Data Vertikal Elemen Kriteria Gabah Kopi

\begin{tabular}{|l|l|}
\hline \multicolumn{1}{|c|}{ Kriteria } & Bobot \\
\hline Harga & 0,1569 \\
\hline Kualitas & 0,6223 \\
\hline Lokasi & 0,2208 \\
\hline Bobot Tujuan & 1 \\
\hline
\end{tabular}

Berikut ini hasil pengolahan data secara vertikal untuk elemen sub kriteria:

Tabel 7. Hasil Pengolahan Data Vertikal Elemen Sub Kriteria Gabah Kopi

\begin{tabular}{|c|c|c|c|c|c|}
\hline \multirow{2}{*}{\multicolumn{2}{|c|}{$\begin{array}{l}\text { Kriteria } \\
\text { Bobot } \\
\text { Kriteria }\end{array}$}} & Harga & Kualitas & Lokasi & \multirow{2}{*}{$\begin{array}{c}\text { Bobot } \\
\text { Sub } \\
\text { Kriteria }\end{array}$} \\
\hline & & 0,1593 & 0,6223 & 0,2208 & \\
\hline \multirow{6}{*}{ 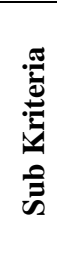 } & $\mathrm{A} 1$ & 0,6940 & & & 0,1089 \\
\hline & $\overline{\mathrm{A} 2}$ & 0,3060 & & & 0,0480 \\
\hline & $\mathrm{A} 3$ & & 0,8083 & & 0,5030 \\
\hline & A4 & & 0,1917 & & 0,1193 \\
\hline & $\overline{\text { A5 }}$ & & & 0,8333 & 0,184 \\
\hline & $\overline{\mathrm{A} 6}$ & & & 0,1667 & 0,0368 \\
\hline
\end{tabular}

Berikut ini hasil pengolahan data secara vertikal untuk elemen alternatif:

Tabel 8. Hasil Pengolahan Data Vertikal Elemen Alternatif Gabah Kopi

\begin{tabular}{|c|c|c|c|c|c|c|c|}
\hline $\begin{array}{l}\text { Sub } \\
\text { Kriteria }\end{array}$ & A1 & A2 & A3 & A4 & A5 & A6 & \\
\hline $\begin{array}{l}\text { Bobot } \\
\text { Sub } \\
\text { Kriteria }\end{array}$ & $\begin{array}{c}0,1 \\
08 \\
9 \\
\end{array}$ & $\begin{array}{c}0,0 \\
48 \\
0 \\
\end{array}$ & $\begin{array}{l}0,5 \\
03\end{array}$ & $\begin{array}{c}0,11 \\
93\end{array}$ & $\begin{array}{l}0,1 \\
84\end{array}$ & $\begin{array}{c}0,0 \\
36 \\
8 \\
\end{array}$ & Bobot \\
\hline $\begin{array}{l}\text { Nelson } \\
\text { L. }\end{array}$ & $\begin{array}{c}0,0 \\
99 \\
0\end{array}$ & $\begin{array}{c}0,0 \\
67 \\
7\end{array}$ & $\begin{array}{r}0,0 \\
501\end{array}$ & $\begin{array}{c}0,09 \\
63\end{array}$ & $\begin{array}{c}0,1 \\
11\end{array}$ & $\begin{array}{c}0,1 \\
23 \\
8\end{array}$ & $\begin{array}{c}0,075 \\
8\end{array}$ \\
\hline $\begin{array}{l}\text { Manump } \\
\text { ol S. }\end{array}$ & $\begin{array}{c}0,0 \\
33 \\
3 \\
\end{array}$ & $\begin{array}{c}0,0 \\
40 \\
8\end{array}$ & $\begin{array}{l}0,0 \\
333\end{array}$ & $\begin{array}{c}0,02 \\
08\end{array}$ & $\begin{array}{l}0,0 \\
117\end{array}$ & $\begin{array}{c}0,0 \\
28 \\
1\end{array}$ & $\begin{array}{c}0,028 \\
1\end{array}$ \\
\hline $\begin{array}{l}\text { Mangana } \\
\text { r N. }\end{array}$ & $\begin{array}{c}0,0 \\
20 \\
9\end{array}$ & $\begin{array}{c}0,1 \\
12 \\
0\end{array}$ & $\begin{array}{r}0,0 \\
711\end{array}$ & $\begin{array}{c}0,03 \\
33\end{array}$ & $\begin{array}{l}0,1 \\
432\end{array}$ & $\begin{array}{c}0,1 \\
23 \\
8\end{array}$ & $\begin{array}{c}0,078 \\
3\end{array}$ \\
\hline
\end{tabular}




\begin{tabular}{|c|c|c|c|c|c|c|c|}
\hline $\begin{array}{l}\text { Sub } \\
\text { Kriteria }\end{array}$ & A1 & A2 & A3 & A4 & A5 & A6 & \\
\hline $\begin{array}{l}\text { Bobot } \\
\text { Sub } \\
\text { Kriteria }\end{array}$ & $\begin{array}{c}0,1 \\
08 \\
9 \\
\end{array}$ & $\begin{array}{c}0,0 \\
48 \\
0 \\
\end{array}$ & $\begin{array}{l}0,5 \\
03\end{array}$ & $\begin{array}{c}0,11 \\
93\end{array}$ & $\begin{array}{c}0,1 \\
84\end{array}$ & $\begin{array}{c}0,0 \\
36 \\
8 \\
\end{array}$ & Bobot \\
\hline $\begin{array}{l}\text { Tongam } \\
\text { A. }\end{array}$ & $\begin{array}{c}0,1 \\
59 \\
8\end{array}$ & $\begin{array}{c}0,1 \\
12 \\
0\end{array}$ & $\begin{array}{c}0,1 \\
592\end{array}$ & $\begin{array}{c}0,15 \\
92\end{array}$ & $\begin{array}{r}0,0 \\
599\end{array}$ & $\begin{array}{c}0,0 \\
79 \\
2\end{array}$ & $\begin{array}{c}0,135 \\
9\end{array}$ \\
\hline Binsar N. & $\begin{array}{c}0,2 \\
01 \\
8\end{array}$ & $\begin{array}{c}0,1 \\
75 \\
1\end{array}$ & $\begin{array}{c}0,1 \\
967\end{array}$ & $\begin{array}{c}0,19 \\
67\end{array}$ & $\begin{array}{l}0,1 \\
819\end{array}$ & $\begin{array}{c}0,1 \\
82 \\
4\end{array}$ & $\begin{array}{c}0,193 \\
0\end{array}$ \\
\hline Gani S. & $\begin{array}{c}0,2 \\
34 \\
3\end{array}$ & $\begin{array}{c}0,1 \\
75 \\
1\end{array}$ & $\begin{array}{r}0,2 \\
335\end{array}$ & $\begin{array}{c}0,23 \\
35\end{array}$ & $\begin{array}{l}0,1 \\
819\end{array}$ & $\begin{array}{c}0,1 \\
82 \\
4\end{array}$ & $\begin{array}{c}0,219 \\
4\end{array}$ \\
\hline $\begin{array}{l}\text { Enfreddy } \\
\text { N. }\end{array}$ & $\begin{array}{c}0,0 \\
13 \\
2\end{array}$ & $\begin{array}{c}0,0 \\
24 \\
9\end{array}$ & $\begin{array}{l}0,0 \\
127\end{array}$ & $\begin{array}{c}0,05 \\
01\end{array}$ & $\begin{array}{l}0,0 \\
271\end{array}$ & $\begin{array}{c}0,0 \\
48 \\
8\end{array}$ & $\begin{array}{c}0,021 \\
8\end{array}$ \\
\hline $\begin{array}{l}\text { Roman } \\
\text { S. }\end{array}$ & $\begin{array}{c}0,1 \\
21 \\
8\end{array}$ & $\begin{array}{c}0,1 \\
12 \\
0\end{array}$ & $\begin{array}{c}0,1 \\
257\end{array}$ & $\begin{array}{c}0,07 \\
11\end{array}$ & $\begin{array}{l}0,1 \\
819\end{array}$ & $\begin{array}{c}0,0 \\
28 \\
1\end{array}$ & $\begin{array}{c}0,124 \\
9\end{array}$ \\
\hline $\begin{array}{l}\text { Mentrona } \\
\mathrm{T} \text {. }\end{array}$ & $\begin{array}{c}0,0 \\
48 \\
2\end{array}$ & $\begin{array}{c}0,1 \\
12 \\
0\end{array}$ & $\begin{array}{r}0,0 \\
208\end{array}$ & $\begin{array}{c}0,01 \\
27\end{array}$ & $\begin{array}{l}0,0 \\
407\end{array}$ & $\begin{array}{c}0,1 \\
23 \\
8\end{array}$ & $\begin{array}{c}0,034 \\
7\end{array}$ \\
\hline $\begin{array}{l}\text { Kambon } \\
\text { o L. }\end{array}$ & $\begin{array}{c}0,0 \\
67 \\
2\end{array}$ & $\begin{array}{c}0,0 \\
67 \\
7\end{array}$ & $\begin{array}{r}0,0 \\
963\end{array}$ & $\begin{array}{c}0,12 \\
57\end{array}$ & $\begin{array}{r}0,0 \\
599\end{array}$ & $\begin{array}{c}0,0 \\
79 \\
2\end{array}$ & $\begin{array}{c}0,088 \\
0\end{array}$ \\
\hline
\end{tabular}

\section{Pengolahan Data Pemilihan Pemasok Greenbean Kopi}

1. Pengolahan Data Secara Horizontal

Hasil pengolahan data horizontal pada pemasok greenbean kopi terdiri dari pengolahan pada elemen kriteria, sub kriteria dan alternatif. Berikut ini hasil pengolahan data secara horizontal untuk elemen kriteria:

Tabel 9. Hasil Pengolahan Data Horizontal Elemen Kriteria Greenbean Kopi

\begin{tabular}{|l|c|c|}
\hline \multicolumn{1}{|c|}{ Kriteria } & Bobot & CR \\
\cline { 1 - 2 } Harga & 0,23 & \\
\cline { 1 - 2 } Kualitas & 0,54 & \\
\cline { 1 - 2 } Reputasi Pemasok & 0,07 & \multirow{2}{*}{0,06} \\
\cline { 1 - 2 } Pelayanan & 0,04 & \\
\cline { 1 - 2 } Kejujuran & 0,12 & \\
\hline
\end{tabular}

Berikut ini hasil pengolahan data secara horizontal untuk elemen sub kriteria:

Tabel 10. Hasil Pengolahan Data Horizontal Elemen Sub Kriteria Greenbean Kopi

\begin{tabular}{|c|l|c|c|c|}
\hline \multicolumn{2}{|l|}{ Kriteria } & Harga & CI & CR \\
\hline \multirow{2}{*}{$\begin{array}{c}\text { Sub } \\
\text { Kriteria }\end{array}$} & $\begin{array}{l}\text { Kecocokan } \\
\text { Harga }\end{array}$ & 0,78 & \multirow{2}{*}{0} & \\
\cline { 2 - 3 } & $\begin{array}{l}\text { Kemudahan } \\
\text { Pembayaran }\end{array}$ & 0,22 & & - \\
\hline
\end{tabular}

\begin{tabular}{|c|c|c|c|c|}
\hline \multicolumn{2}{|l|}{ Kriteria } & Kualitas & CI & CR \\
\hline \multirow{2}{*}{$\begin{array}{c}\text { Sub } \\
\text { Kriteria }\end{array}$} & $\begin{array}{l}\text { Kesesuaian } \\
\text { Greenbean } \\
\text { dengan } \\
\text { Spesifikasi }\end{array}$ & 0,808 & \multirow{2}{*}{0} & \multirow{2}{*}{-} \\
\hline & $\begin{array}{l}\text { Pasokan } \\
\text { dengan } \\
\text { Kualitas } \\
\text { Konstan }\end{array}$ & 0,192 & & \\
\hline \multicolumn{2}{|l|}{ Kriteria } & $\begin{array}{l}\text { Reputasi } \\
\text { Pemasok }\end{array}$ & CI & CR \\
\hline \multirow{2}{*}{$\begin{array}{c}\text { Sub } \\
\text { Kriteria }\end{array}$} & $\begin{array}{l}\text { Kualitas } \\
\text { Pasokan }\end{array}$ & 0,7806 & \multirow[b]{2}{*}{0} & \multirow[b]{2}{*}{-} \\
\hline & $\begin{array}{l}\text { Hubungan } \\
\text { dengan } \\
\text { Pelanggan } \\
\end{array}$ & 0,2194 & & \\
\hline \multicolumn{2}{|l|}{ Kriteria } & Pelayanan & CI & CR \\
\hline \multirow{3}{*}{$\underset{\text { Kriteria }}{\text { Sub }}$} & $\begin{array}{l}\text { Layanan } \\
\text { Pengiriman }\end{array}$ & 0,0719 & \multirow{3}{*}{0,05} & \multirow{3}{*}{0,09} \\
\hline & $\begin{array}{l}\text { Ketersediaan } \\
\text { Greenbean }\end{array}$ & 0,589 & & \\
\hline & $\begin{array}{l}\text { Kemudahan } \\
\text { Dihubungi }\end{array}$ & 0,3391 & & \\
\hline \multicolumn{2}{|l|}{ Kriteria } & Kejujuran & CI & CR \\
\hline \multirow{2}{*}{$\begin{array}{c}\text { Sub } \\
\text { Kriteria }\end{array}$} & $\begin{array}{l}\text { Asal } \\
\text { Greenbean }\end{array}$ & 0,8333 & \multirow[b]{2}{*}{0} & \multirow[b]{2}{*}{-} \\
\hline & $\begin{array}{l}\text { Berat } \\
\text { Greenbean } \\
\text { Dipasok }\end{array}$ & 0,1667 & & \\
\hline
\end{tabular}

Berikut ini hasil pengolahan data secara horizontal untuk elemen alternatif:

Tabel 11. Hasil Pengolahan Data Horizontal Elemen Alternatif Greenbean Kopi

\begin{tabular}{|c|c|c|c|c|}
\hline \multirow{2}{*}{$\begin{array}{c}\text { Sub } \\
\text { Kriteria }\end{array}$} & \multicolumn{3}{|c|}{ Alternatif } & \multirow{2}{*}{ CR } \\
\hline & $\begin{array}{c}\text { TOKE } \\
\text { MS }\end{array}$ & $\begin{array}{c}\text { TOKE } \\
\text { MUNTHE }\end{array}$ & $\begin{array}{l}\text { TOKE } \\
\text { M18 }\end{array}$ & \\
\hline $\begin{array}{l}\text { Kecocokan } \\
\text { Harga }\end{array}$ & 0,696 & 0,2249 & 0,0790 & 0,08 \\
\hline $\begin{array}{l}\text { Kemudahan } \\
\text { Pembayaran }\end{array}$ & 0,590 & 0,3391 & 0,0719 & 0,09 \\
\hline $\begin{array}{l}\text { Kesesuaian } \\
\text { Greenbean } \\
\text { dengan } \\
\text { Spesifikasi }\end{array}$ & 0,589 & 0,0719 & 0,3391 & 0,09 \\
\hline $\begin{array}{l}\text { Pasokan } \\
\text { dengan } \\
\text { Kualitas } \\
\text { Konstan }\end{array}$ & 0,560 & 0,0753 & 0,3643 & 0,02 \\
\hline $\begin{array}{l}\text { Kualitas } \\
\text { Pasokan }\end{array}$ & 0,560 & 0,0753 & 0,3643 & 0,02 \\
\hline $\begin{array}{l}\text { Hubungan } \\
\text { dengan } \\
\text { Pelanggan }\end{array}$ & 0,225 & 0,0790 & 0,6961 & 0,08 \\
\hline
\end{tabular}




\begin{tabular}{|l|c|c|c|c|}
\hline \multirow{2}{*}{\multicolumn{1}{c|}{$\begin{array}{c}\text { Sub } \\
\text { Kriteria }\end{array}$}} & \multicolumn{3}{|c|}{ Alternatif } & \multirow{2}{*}{ CR } \\
\cline { 2 - 4 } & $\begin{array}{c}\text { TOKE } \\
\text { MS }\end{array}$ & $\begin{array}{c}\text { TOKE } \\
\text { MUNTHE }\end{array}$ & $\begin{array}{c}\text { TOKE } \\
\text { M18 }\end{array}$ & \\
\hline $\begin{array}{l}\text { Layanan } \\
\text { Pengiriman }\end{array}$ & 0,696 & 0,0790 & 0,2249 & 0,08 \\
\hline $\begin{array}{l}\text { Ketersediaan } \\
\text { Greenbean }\end{array}$ & 0,696 & 0,0790 & 0,2249 & 0,08 \\
\hline $\begin{array}{l}\text { Kemudahan } \\
\text { Dihubungi }\end{array}$ & 0,729 & 0,0921 & 0,1793 & 0,01 \\
\hline $\begin{array}{l}\text { Asal } \\
\text { Greenbean }\end{array}$ & 0,589 & 0,0719 & 0,3391 & 0,09 \\
\hline $\begin{array}{l}\text { Berat } \\
\text { Greenbean } \\
\text { Dipasok }\end{array}$ & 0,641 & 0,1211 & 0,2375 & 0,01 \\
\hline
\end{tabular}

\section{Pengolahan Data Secara Vertikal}

Hasil pengolahan data vertikal pada pemasok greenbean kopi terdiri dari pengolahan pada elemen kriteria, sub kriteria dan alternatif. Berikut ini hasil pengolahan data secara vertikal untuk elemen kriteria:

Tabel 12. Hasil Pengolahan Data Vertikal Elemen Kriteria Greenbean Kopi

\begin{tabular}{|l|c|}
\hline \multicolumn{1}{|c|}{ Kriteria } & Bobot Kriteria \\
\hline Harga & 0,23 \\
\hline Kualitas & 0,54 \\
\hline Reputasi Pemasok & 0,07 \\
\hline Pelayanan & 0,04 \\
\hline Kejujuran & 0,12 \\
\hline Bobot Tujuan & 1 \\
\hline
\end{tabular}

Berikut ini hasil pengolahan data secara vertical untuk elemen kriteria:

Tabel 13. Hasil Pengolahan Data Vertikal

Elemen Sub Kriteria Greenbean Kopi

\begin{tabular}{|c|c|c|c|}
\hline \multirow{2}{*}{\multicolumn{2}{|c|}{$\begin{array}{l}\text { Kriteria } \\
\text { Bobot Kriteria }\end{array}$}} & Harga & \multirow{2}{*}{$\begin{array}{c}\text { Bobot } \\
\text { Sub } \\
\text { Kriteria }\end{array}$} \\
\hline & & 0,23 & \\
\hline \multirow{2}{*}{$\begin{array}{c}\text { Sub } \\
\text { Kriteria }\end{array}$} & $\begin{array}{l}\text { Kecocokan } \\
\text { Harga }\end{array}$ & 0,7806 & 0,1811 \\
\hline & $\begin{array}{l}\text { Kemudahan } \\
\text { Pembayaran }\end{array}$ & 0,2194 & 0,0509 \\
\hline \multicolumn{2}{|l|}{ Kriteria } & Kualitas & \multirow{2}{*}{$\begin{array}{c}\text { Bobot } \\
\text { Sub } \\
\text { Kriteria }\end{array}$} \\
\hline \multicolumn{2}{|c|}{ Bobot Kriteria } & 0,54 & \\
\hline \multirow{2}{*}{$\begin{array}{c}\text { Sub } \\
\text { Kriteria }\end{array}$} & $\begin{array}{l}\text { Kesesuaian } \\
\text { Greenbean } \\
\text { dengan } \\
\text { Spesifikasi }\end{array}$ & 0,8083 & 0,4381 \\
\hline & $\begin{array}{l}\text { Pasokan } \\
\text { dengan } \\
\text { Kualitas } \\
\text { Konstan }\end{array}$ & 0,1917 & 0,1039 \\
\hline
\end{tabular}

\begin{tabular}{|c|c|c|c|}
\hline \multicolumn{2}{|l|}{ Kriteria } & $\begin{array}{l}\text { Reputasi } \\
\text { Pemasok }\end{array}$ & $\begin{array}{l}\text { Bobot } \\
\text { Sub }\end{array}$ \\
\hline \multicolumn{2}{|c|}{ Bobot Kriteria } & 0,07 & Kriteria \\
\hline \multirow[b]{2}{*}{$\begin{array}{c}\text { Sub } \\
\text { Kriteria }\end{array}$} & $\begin{array}{l}\text { Kualitas } \\
\text { Pasokan }\end{array}$ & 0,7806 & 0,0546 \\
\hline & $\begin{array}{l}\text { Hubungan } \\
\text { dengan } \\
\text { Pelanggan }\end{array}$ & 0,2194 & 0,0154 \\
\hline \multicolumn{2}{|l|}{ Kriteria } & Pelayanan & Bobot \\
\hline \multicolumn{2}{|c|}{ Bobot Kriteria } & 0,04 & $\begin{array}{c}\text { Sub } \\
\text { Kriteria }\end{array}$ \\
\hline \multirow{3}{*}{$\begin{array}{c}\text { Sub } \\
\text { Kriteria }\end{array}$} & $\begin{array}{l}\text { Layanan } \\
\text { Pengiriman }\end{array}$ & 0,0719 & 0,0028 \\
\hline & $\begin{array}{l}\text { Ketersediaan } \\
\text { Greenbean }\end{array}$ & 0,589 & 0,023 \\
\hline & $\begin{array}{l}\text { Kemudahan } \\
\text { Dihubungi }\end{array}$ & 0,3391 & 0,0132 \\
\hline \multicolumn{2}{|l|}{ Kriteria } & Kejujuran & Bobot \\
\hline \multicolumn{2}{|c|}{ Bobot Kriteria } & 0,12 & $\begin{array}{c}\text { Sub } \\
\text { Kriteria }\end{array}$ \\
\hline \multirow{2}{*}{$\begin{array}{c}\text { Sub } \\
\text { Kriteria }\end{array}$} & $\begin{array}{l}\text { Asal } \\
\text { Greenbean }\end{array}$ & 0,8333 & 0,0975 \\
\hline & $\begin{array}{l}\text { Berat } \\
\text { Greenbean } \\
\text { Dipasok }\end{array}$ & 0,1667 & 0,0195 \\
\hline
\end{tabular}

Berikut ini hasil pengolahan data secara vertikal untuk elemen alternatif:

Tabel 14. Hasil Pengolahan Data Vertikal Elemen Alternatif Greenbean Kopi

\begin{tabular}{|c|c|c|c|c|}
\hline \multirow{2}{*}{$\begin{array}{l}\text { Sub } \\
\text { Kriteria }\end{array}$} & \multirow{2}{*}{$\begin{array}{c}\text { Bobot } \\
\text { Sub } \\
\text { Kriteria } \\
\end{array}$} & \multicolumn{3}{|c|}{ Alternatif } \\
\hline & & $\begin{array}{c}\text { TOKE } \\
\text { MS }\end{array}$ & $\begin{array}{c}\text { TOKE } \\
\text { MUNTHE }\end{array}$ & $\begin{array}{l}\text { TOKE } \\
\text { M18 } \\
\end{array}$ \\
\hline $\begin{array}{l}\text { Kecocokan } \\
\text { Harga }\end{array}$ & 0,1811 & 0,696 & 0,2249 & 0,079 \\
\hline $\begin{array}{l}\text { Kemudahan } \\
\text { Pembayaran }\end{array}$ & 0,0509 & 0,589 & 0,3391 & 0,072 \\
\hline $\begin{array}{l}\text { Kesesuaian } \\
\text { Greenbean } \\
\text { dengan } \\
\text { Spesifikasi }\end{array}$ & 0,4381 & 0,589 & 0,0719 & 0,339 \\
\hline $\begin{array}{l}\text { Pasokan } \\
\text { dengan } \\
\text { Kualitas } \\
\text { Konstan }\end{array}$ & 0,1039 & 0,560 & 0,0753 & 0,364 \\
\hline $\begin{array}{l}\text { Kualitas } \\
\text { Pasokan }\end{array}$ & 0,0546 & 0,560 & 0,0753 & 0,364 \\
\hline $\begin{array}{l}\text { Hubungan } \\
\text { dengan } \\
\text { Pelanggan }\end{array}$ & 0,0154 & 0,225 & 0,0790 & 0,696 \\
\hline $\begin{array}{l}\text { Layanan } \\
\text { Pengiriman }\end{array}$ & 0,0028 & 0,696 & 0,0790 & 0,225 \\
\hline $\begin{array}{l}\text { Ketersedian } \\
\text { Greenbean }\end{array}$ & 0,023 & 0,696 & 0,0790 & 0,225 \\
\hline $\begin{array}{l}\text { Kemudahan } \\
\text { Dihubungi }\end{array}$ & 0,0132 & 0,729 & 0,0921 & 0,179 \\
\hline $\begin{array}{l}\text { Asal } \\
\text { Greenbean }\end{array}$ & 0,0975 & 0,589 & 0,0719 & 0,339 \\
\hline
\end{tabular}




\begin{tabular}{|l|c|c|c|c|}
\hline \multirow{2}{*}{$\begin{array}{l}\text { Sub } \\
\text { Kriteria }\end{array}$} & \multirow{2}{*}{$\begin{array}{c}\text { Bobot } \\
\text { Sub } \\
\text { Kriteria }\end{array}$} & $\begin{array}{c}\text { TOKE } \\
\text { MS }\end{array}$ & $\begin{array}{c}\text { TOKE } \\
\text { MUNTHE }\end{array}$ & $\begin{array}{c}\text { TOKE } \\
\text { M18 }\end{array}$ \\
\cline { 3 - 5 } & & & & Alternatif \\
$\begin{array}{l}\text { Berat } \\
\text { Greenbean } \\
\text { Dipasok }\end{array}$ & 0,0195 & 0,641 & 0,1211 & 0,237 \\
\hline \multicolumn{2}{|l|}{ Bobot Alternatif } & 0,604 & 0,115 & 0,281 \\
\hline
\end{tabular}

\section{Analisis Hasil Pengolahan Data}

1. Pemasok Gabah Kopi

Dari hasil pengolahan data secara horizontal dan vertikal maka dapat di analisis urutan prioritas dari setiap elemen. Berikut ini adalah urutan prioritas dari elemen kriteria pada pemilihan pemasok gabah kopi:

Tabel 15. Urutan Prioritas Kriteria Pemasok Gabah Kopi

\begin{tabular}{|l|c|c|}
\hline \multicolumn{1}{|c|}{ Kriteria } & Bobot & Prioritas \\
\hline Harga & 0,1569 & 3 \\
\hline Kualitas & 0,6223 & $\mathbf{1}$ \\
\hline Lokasi & 0,2208 & 2 \\
\hline
\end{tabular}

Berikut ini adalah urutan prioritas dari elemen sub kriteria pada pemilihan pemasok gabah kopi:

Tabel 16. Urutan Prioritas Sub Kriteria Pemasok Gabah Kopi

\begin{tabular}{|l|r|c|}
\hline \multicolumn{1}{|c|}{ Sub Kriteria } & \multicolumn{1}{c|}{ Bobot } & Prioritas \\
\hline $\begin{array}{l}\text { Kesesuaian Harga } \\
\text { dengan Spesifikasi }\end{array}$ & 0,1089 & 4 \\
\hline $\begin{array}{l}\text { Kemudahan } \\
\text { Pembayaran }\end{array}$ & 0,0480 & 5 \\
\hline $\begin{array}{l}\text { Kesesuaian Gabah } \\
\text { dengan Spesifikasi }\end{array}$ & 0,5030 & $\mathbf{1}$ \\
\hline $\begin{array}{l}\text { Kemampuan untuk } \\
\text { Kualitas Konstan }\end{array}$ & 0,1193 & 3 \\
\hline Lokasi Lahan Kopi & 0,184 & 2 \\
\hline Jarak Pemasok & 0,0368 & 6 \\
\hline
\end{tabular}

Berikut ini adalah urutan prioritas dari elemen sub alternatif pada pemilihan pemasok gabah kopi:

Tabel 17. Urutan Prioritas Pemasok Gabah Kopi

\begin{tabular}{|l|c|c|}
\hline \multicolumn{1}{|c|}{ Alternatif } & Bobot & Prioritas \\
\hline $\begin{array}{l}\text { Nelson } \\
\text { Lumbantoruan }\end{array}$ & 0,0758 & 7 \\
\hline Manumpol Silaban & 0,0281 & 9 \\
\hline
\end{tabular}

\begin{tabular}{|l|c|c|}
\hline \multicolumn{1}{|c|}{ Alternatif } & Bobot & Prioritas \\
\hline Manganar Nababan & 0,0783 & 6 \\
\hline Tongam Aritonang & 0,1359 & 3 \\
\hline Binsar Nababan & 0,1930 & 2 \\
\hline Gani Silaban & 0,2194 & $\mathbf{1}$ \\
\hline Enfreddy Nababan & 0,0218 & 10 \\
\hline Roman Silaban & 0,1249 & 4 \\
\hline $\begin{array}{l}\text { Mentrona } \\
\text { Tambunan }\end{array}$ & 0,0347 & 8 \\
\hline $\begin{array}{l}\text { Kambono } \\
\text { Lumbantoruan }\end{array}$ & 0,0880 & 5 \\
\hline
\end{tabular}

\section{Pemasok Greenbean Kopi}

Berdasarkan hasil pengolahan data secara horizontal dan vertikal maka dapat di analisis urutan prioritas dari setiap elemen. Berikut ini adalah urutan prioritas dari elemen kriteria pada pemilihan pemasok greenbean kopi:

Tabel 18. Urutan Prioritas Kriteria Pemasok Greenbean Kopi

\begin{tabular}{|l|c|c|}
\hline \multicolumn{1}{|c|}{ Kriteria } & $\begin{array}{c}\text { Bobot } \\
\text { Kriteria }\end{array}$ & Prioritas \\
\hline Harga & 0,23 & 2 \\
\hline Kualitas & 0,54 & $\mathbf{1}$ \\
\hline Reputasi Pemasok & 0,07 & 4 \\
\hline Pelayanan & 0,04 & 5 \\
\hline Kejujuran & 0,12 & 3 \\
\hline
\end{tabular}

Berikut ini adalah urutan prioritas dari elemen sub kriteria pada pemilihan pemasok greenbean kopi:

Tabel 19. Urutan Prioritas Sub Kriteria Pemasok Greenbean Kopi

\begin{tabular}{|l|c|c|}
\hline \multicolumn{1}{|c|}{ Sub Kriteria } & Bobot & Prioritas \\
\hline Kecocokan Harga & 0,1811 & 2 \\
\hline Kemudahan Pembayaran & 0,0509 & 6 \\
\hline $\begin{array}{l}\text { Kesesuaian Greenbean } \\
\text { dengan Spesifikasi }\end{array}$ & 0,4381 & $\mathbf{1}$ \\
\hline $\begin{array}{l}\text { Pasokan dengan Kualitas } \\
\text { Konstan }\end{array}$ & 0,1039 & 3 \\
\hline Kualitas Pasokan & 0,0546 & 5 \\
\hline $\begin{array}{l}\text { Hubungan dengan } \\
\text { Pelanggan }\end{array}$ & 0,0154 & 9 \\
\hline Layanan Pengiriman & 0,0028 & 11 \\
\hline Ketersediaan Greenbean & 0,023 & 7 \\
\hline Kemudahan Dihubungi & 0,0132 & 10 \\
\hline Asal Greenbean & 0,0975 & 4 \\
\hline Berat Greenbean Dipasok & 0,0195 & 8 \\
\hline
\end{tabular}


Berikut ini adalah urutan prioritas dari elemen alternatif pada pemilihan pemasok greenbean kopi:

Tabel 20. Urutan Prioritas Alternatif Pemasok Greenbean Kopi

\begin{tabular}{|l|c|c|}
\hline \multicolumn{1}{|c|}{ Alternatif } & Bobot & Prioritas \\
\hline TOKE MS & 0,6039 & $\mathbf{1}$ \\
\hline $\begin{array}{l}\text { TOKE } \\
\text { MUNTHE }\end{array}$ & 0,1153 & 3 \\
\hline TOKE M18 & 0,2808 & 2 \\
\hline
\end{tabular}

\section{KESIMPULAN}

Berdasarkan penelitian yang telah dilakukan, maka dapat disimpulkan sebagai berikut:

1. Kriteria dalam pemilihan pemasok gabah kopi adalah harga, kualitas dan lokasi dengan sub kriteria yaitu kesesuaian harga dengan spesifikasi, kemudahan pembayaran, kesesuaian gabah dengan spesifikasi, kemampuan untuk kualitas konstan, lokasi lahan kopi dan jarak pemasok. Sedangkan untuk pemilihan pemasok greenbean kopi kriterianya adalah harga, kualitas, reputasi pemasok, pelayanan, dan kejujuran. Sub kriteria yaitu kecocokan harga, kemudahan pembayaran, kesesuaian greenbean dengan spesifikasi, pasokan dengan kualitas konstan, reputasi kualitas pasokan, reputasi hubungan dengan pelanggan, layanan pengiriman, ketersediaan greenbean, kejujuran asal greenbean dan kejujuran berat pasokan greenbean.

2. Kriteria yang paling penting dalam pemilihan pemasok gabah kopi adalah kualitas $(0,6254)$ dan sub kriteria yang paling penting adalah kesesuaian gabah dengan spesifikasi (0,5055). Sedangkan untuk pemilihan pemasok greenbean kopi, kriteria yang paling penting adalah kualitas $(0,5869)$ dan sub kriteria yang paling penting adalah kesesuaian greenbean dengan spesifikasi $(0,4744)$.

3. Pemasok yang paling potensial untuk KSU POM Humbang Cooperative pada pemasok gabah kopi adalah Gani Silaban (0.2646) dan pemasok greenbean kopi adalah Toke MS $(0,6448)$.

\section{DAFTAR PUSTAKA}

Firdaus , M., \& M.A, F. (2008). Aplikasi Metode Kuantitatif Terpilih Untuk Manajemen dan Bisnis. Bogor: IPB Press.

Heizer, J., \& Render, B. (2001). Operations Management. Jakarta: Salemba Empat.

Permadi, B. (1992). AHP. Jakarta: PAUEK-UI.

Poirier, C. C. (2004). Using Models to Improve Supply Chain. New York: St. Lucie Press.

Pujawan, I. (2005). Supply Chain Management. Surabaya: Guna Widya.

Saaty, T. (1991). Pengambilan Keputusan Bagi Para Pemimpin. Jakarta: PT. Pustaka Binaman Pressindo.

Saaty, T., \& Vargas, L. (2012). Models, Methods. Concepts \& Applications of The Analytic Hierarchy Process. New York: Springer.

Saputra, T. (2018). Penentuan Kriteria dalam Pemilihan Supplier Bahan Kain pada Industri Textile dengan Menggunakan Metode Analytical Hierarchy Process (AHP). Yogyakarta: Universitas Islam Indonesia.

Setyani, S. (2018). Evaluasi Nilai Cacat dan Cita Rasa Kopi Robusta (Coffea canephora L.) yang 
Diproduksi IKM Kopi di

Kabupaten Tanggamus. Jurnal

Teknologi \& Industri Hasil

Pertani, 103-114.

Shah, K., \& Gorty, V. (2011). Technology

System and Management. Mumbai:

Springer.

Towaha, J., \& Rubiyo. (2016). Mutu Fisik

Biji dan Citarasa Kopi Arabika

Hasil Fermentasi Mikrob Pribiotik

Asal Pencernaan Luwak. J. TIDP, 61-70.

Tunggal, A. (2009). Supply Chain Management (Manajemen Rantai Pasokan). Jakarta: Harvarindo.

Viarani, S., \& Zadry, H. (2015). Analisis

Pemilihan Pemasok dengan Metode Analytical Hierarchy

Process di Proyek Indarung VI PT

Semen Padang. Jurnal Laporan

Kerja Praktek, 50-70. 